\title{
A capacidade criativa e o vírus do capitalismo
}

Adriana F. Martinez é Doutora e graduada em Ciências Sociais pela PUC-SP, mestre em Integração Latino-americana pela USP. Dedicada, nas últimas pesquisas, ao estudo da racionalidade neoliberal e os efeitos políticos das produções provenientes da economia criativa no governo de condutas, em especial, do design.<drimartinez@yahoo.com.br/ drimartinez.5@gmail.com> ORCID: 0000-0001-6613-419X
Resumo $O$ ano de 2020 foi marcado pela propagação planetária do novo coronavírus que transformou brutalmente o cotidiano das pessoas. E, apesar de 2021 ter-se iniciado com a expectativa de imunização pelas vacinas, que muito lentamente começaram a ser aplicadas, ainda se convive com o alto índice de mortes diárias, principalmente no Brasil. A finalidade deste artigo consiste em mostrar como a presente pandemia é efeito do capitalismo ancorado no governo da racionalidade neoliberal. Assinala-se também de que modo os procedimentos técnicos de criatividade e inovação contribuem com a atualização do regime capitalista, ao implantar projetos que garantem a melhor concorrência. Por fim, propõe-se a possibilidade de pensar como interceptar essa lógica.

Palavras chave Covid-19, Criatividade inovadora, Projetos, Capitalismo, Racionalidade neoliberal. 


\section{The creative capacity and the capitalism virus}

Abstract The year 2020 was marked by the global spread of the new coronavirus that has brutally transformed people's everyday life. And although 2021 started with the expectation of immunization by vaccines, which very slowly initiated to be applied, there is still a high rate of daily deaths, especially in Brazil. The purpose of this article is to show how the current pandemic is the effect of capitalism anchored in the government of neoliberal rationality. Another aspect analysed is how the technical procedures of creativity and innovation contribute to the updating of the capitalist regime by implementing projects that guarantee the best competition. Finally, it is considered in this article the possibility of pondering how to intercept this logic.

Keywords Covid-19, Innovative creativity, Projects, Capitalism, Neoliberal rationality.

\section{La capacidad creativa y el virus del capitalismo}

Resumen El año 2020 fue marcado por la propagación planetaria del nuevo coronavirus que transformó brutalmente la vida cotidiana de las personas. Y aunque 2021 inició con la expectativa de inmunización por vacunas, que muy lentamente se ha comenzado a aplicar, todavía hay una alta tasa de muertes diarias, especialmente en Brasil. El propósito de este artículo es mostrar cómo la pandemia actual es el efecto del capitalismo anclado en el gobierno de la racionalidad neoliberal. Se observa también de qué manera los procedimientos técnicos de creatividad e innovación contribuyen para la actualización del régimen capitalista mediante la implantación de proyectos que garanticen una mejor competencia. Por último, se propone pensar la posibilidad de cómo interceptar esta lógica.

Palabras clave Covid-19, Creatividad innovadora, Proyectos, Capitalismo, Racionalidad neoliberal. 


\section{Introdução}

Tudo ocorreu rapidamente. Era 10 de março de 2020 quando eu e alguns amigos comentávamos acerca do primeiro caso confirmado do novo coronavírus (coV) ou Sars-Cov-2 no Brasil. Tratava-se de um homem de 61 anos que havia voltado de uma viagem da Itália onde, nesse momento, registrava-se um aumento considerável da doença covid-19. Parecia um evento isolado, bem específico, afastado da nossa cadência rotineira. Uma semana depois, comunicavam-se a primeira morte, o decreto de estado de emergência na cidade de São Paulo e o crescimento acelerado do número de casos pelo mundo afora. Muitos de nós estamos, há um ano, adiando encontros e torcendo para que a disputa política sobre a vacina não retarde demais a imunização. Não se sabe ao certo se é a terceira, a segunda ou se ainda não saímos da primeira onda, mas sabe-se que já circulam, intercontinentalmente, mutações nas variantes britânica, sul-africana e brasileira do novo coronavírus, agora nem tão novo assim. Entretanto, o presidente em exercício, Jair Bolsonaro, discute os efeitos colaterais de virar jacaré ou questiona a eficiência da chamada - por ele e seus seguidores - "vacina comunista," uma vez que foi formulada na China. Sem mencionar os sucessivos disparates propagados pelo mandatário como tomar vermífugo, remédios sem eficácia comprovada ou ridicularizar o uso de máscara, entre outros absurdos. E no mesmo contexto em que ele espalha sua truculência, pessoas morrem por falta de oxigênio, leitos em UTI's, insumos, equipamentos hospitalares etc. Enquanto escrevo este texto, em meados de março de 2021, o Brasil supera a marca dos 2000 mortos por dia ${ }^{1}$.

Durante todo este período, proliferaram publicações de artigos, livros, matérias jornalísticas em muitas áreas do conhecimento, as quais pretendem explicar, sob diferentes ângulos, os impactos da covid-19. Eu escolhi como ponto de partida evidenciar que esta pandemia é efeito do capitalismo exercido por meio da racionalidade política neoliberal, compreendida aqui não como ideologia, mas como a capacidade de fazer conexões eficazes em um campo de práticas para agir sobre as condutas (FOUCAULT, 2008). Isso é válido para capitalistas envoltos em governos democráticos, governos comunistas enredados no capitalismo, bem como estados ditatoriais, porque, para além do modelo de produção capitalista reproduzido globalmente, o que os une, e a todos perpassa, é justamente o conjunto de ações elaboradas para atingir os fins propostos pelo neoliberalismo.

O capitalismo está em permanente atualização, e dentre as suas principais molas propulsoras na contemporaneidade encontram-se as atividades consideradas criativas, pois propiciam, tanto nos sujeitos quanto nas corporações, melhores oportunidades competitivas. Não por acaso, a atividade projetual oriunda das práticas criativas ingressou em quase todos os processos da vida com a finalidade de introduzir algo novo. A propósito, a noção de projeto indica essa característica permanente de promover a novidade ou a inovação, pois a própria etimologia (do latim prõjectus ${ }^{2}$ ) denota 
a conotação de estar à frente. Esboçar-se em projetos criativos é, então, uma autoprodução ilimitada, logo o insucesso equivale à falta de criatividade ou corresponde a um projeto mal executado. Ao reconhecer-se como indivíduo dotado de criatividade, capaz de introduzir novidades no seu cotidiano imediato, efetivam-se relações de poder contidas em projetos que resultam numa forma eficaz de sujeição.

A corrida pela novidade produz implicações nos discursos pautados em formulações como nova economia, termo utilizado desde a década de 1990 para demarcar a transição de uma economia industrial baseada em bens tangíveis para uma de bens intangíveis escorada na criatividade, ou nova política, expressão cunhada no final do século passado, a partir dos movimentos antiglobalização. Designações que foram capturadas, moldadas e encerram um novo condizente com os atributos de inovação. Um dos pioneiros em elogiar a inovação no sentido de um novo recurso foi Joseph Schumpeter (2017). Para explicar as transformações no capitalismo, ele parte da premissa de ser este um sistema instável, evolutivo e concorrencial. Adotou a noção de "destruição criativa" como fenômeno ocorrido após alguma modificação nos meios de produção, inserção de novos bens de consumo no mercado, expansão mercadológica, alterações administrativas. Segundo o autor, a "destruição criativa" apresenta dois lados: um se refere ao favorecimento dos empresários inovadores; o outro, a indivíduos ou empresas que podem ficar transitoriamente fora do mercado, não conseguir integrar-se a este, ou nunca mais voltar a desfrutar dos benefícios da situação anterior. Schumpeter atribui ao capitalismo a inevitabilidade da relação dor e dano, uma vez que a inovação varre a ordem anterior. Ante isso, Schumpeter carece de qualquer novidade, pois justifica o próprio capitalismo como produtor de misérias e reservas de capital humano, a ser utilizado quando necessário. Inovação, nesses termos, é uma solução prática para determinada ocasião, não é invenção extraordinária, assim como "destruição criativa" não rompe com os laços societários fundados no capitalismo, mas indica períodos econômicos bem-sucedidos.

Desde os anos de 1980, houve um rearranjo da "destruição criativa" schumpeteriana para a "produção criativa" em proveito do crescimento econômico, quer de alguns países ou regiões, quer daqueles que conseguem investir em si. Explorar a difusão da criatividade ligada à inovação tornou-se essencial à racionalidade neoliberal, na medida em que aumenta as chances de competitividade no mercado concorrencial. Ademais, a relação entre o potencial de inovação e a criatividade organiza a modalidade da economia criativa, a qual transforma espaços, produção, relações de trabalho, práticas políticas e estratégias de governo. Tal concepção econômica enfatiza a importância da criatividade como qualidade fundamental na constituição da economia, especialmente na formação do capital humano-criativo, sinalizando o deslocamento do modelo de produção industrial calcado na capacidade física do trabalhador para os processos de gestão e investimentos em inteligências. A concepção do capital humano-criativo, por sua vez, coaduna com o projeto social da racionalidade neoliberal, em 
que todo indivíduo deve ter rendimentos suficientes para "se garantir por si mesmo contra os riscos que existem, ou também contra os riscos da existência, ou também contra essa fatalidade da existência que são a velhice e a morte" (FOUCAULT, 2008, p. 197).

Após a II Guerra Mundial, particularmente depois do lançamento do satélite soviético Sputnik (1957), os EUA identificaram deficiências de um conhecimento específico voltado à geração de "inteligências criativas". Esse foi o pontapé inicial para se organizar o ensino de processos criativos, inseridos, gradativamente, na economia, em programas governamentais e no cotidiano das pessoas. Contudo, foi depois do evento Eco- $92^{3}$, com a subscrição da Agenda $21^{4}$, que profissões ligadas ao "universo criativo" passaram a adotar mudanças e assumir o compromisso de melhorar aspectos sociais, culturais, econômicos e ambientais no intuito de responder à demanda econômica. Pois bem, ao abordar os procedimentos de inovação, exigidos no mercado concorrencial, é possível diagnosticar uma governamentalidade - ou seja, a condução da própria conduta e dos outros - atravessada pela tecnologia de poder proveniente da criatividade e absorvida pela racionalidade neoliberal (MARTINEZ, 2020).

De maneira alguma pretende-se, na abordagem deste artigo, subestimar quem consegue sair de um entrave por conta própria, tampouco invalidar as experiências praticadas enquanto reinvenção individual ou coletiva. A problematização aqui é dirigida à criatividade como valor e aplicabilidade universal, utilizada para inovar, tendo em vista aprimorar a concorrência dos sujeitos entre si ou entre corporações.

Trata-se da criatividade que redimensiona o sujeito econômico, empresário de si, estudado por Michel Foucault, sendo novamente uma forma efetiva de governo posto que ratifica um modelo de vida empresa como "poder enformador da sociedade". Por isso, o conceito "empresa" não é atrelado meramente às grandes empresas de escala nacional, internacional ou estatal, mas relacionado ao exercício que, "no interior do corpo social", forma "o escopo da política neoliberal" (FOUCAULT, 2008, p. 203).

Nesta perspectiva, as páginas a seguir mostram como o aparecimento do novo coronavírus é fruto dos sistemas produtivos capitalistas, e o modo pelo qual os projetos da economia criativa de mercado, incrustados no cerne da racionalidade neoliberal, beneficiaram a propagação da covid-19. Cabe questionar se, no contexto pós-pandemia, essas práticas continuarão vigentes ou se elas serão renovadas, e que possibilidades há de fazê-las cambalear.

\section{Aglomerados de gente}

A década de 1970 pode ser considerada um marco para a emergência da teoria de educação baseada no pressuposto do desenvolvimento individual intrínseco ao desenvolvimento econômico. Tal visão sugere a valorização de si próprio na mesma medida em que se valoriza o capital. Capitali- 
zar-se é o objetivo da teoria do capital humano, deslocando para a esfera individual os problemas sociais, a obtenção de renda para sobrevivência e a formação profissional com vistas à melhor concorrência. A educação formal passou a ser um valor econômico, equacionando-se a fórmula capital-trabalho em capital-capital humano. Assim, o salário não remete mais ao preço de venda da força de trabalho, mas a uma renda. Renda-produto, renda-rendimento de capital, conectada a fatores físicos e psicológicos mediante os quais as pessoas têm capacidade de ganhar um salário (Ibidem).

$\mathrm{Na}$ contemporaneidade, sem tirar essa concepção de cena e para se assegurar a eficácia do capital humano, a criatividade transformou-se na antessala da inovação, e esta última é utilizada como estímulo para ativar o mercado. Do mesmo modo que qualquer empreendimento empresarial, a proposta de inovação do empresário de si assume a busca por melhorias cotidianas, quando aprimora o conhecimento e estabelece um processo estratégico para afiançar sucesso nos negócios, na qualidade de lugar e de vida. A criatividade, nesta dimensão, serve como fluxo contínuo para a inovação oportuna do capital humano. De acordo com o grau de criatividade empregado, é possível discriminar os indivíduos que angariaram, no decurso da vida, capacidade suficiente para garantir a sua existência. Uma avaliação que tem como objetivo atestar quem se encontra na curva ascendente, em direção à sobrevivência, ou na descendente, rumo à miséria e ao perecimento. Daí, para ser um sujeito economicamente ativo, capaz de valer-se do seu trabalho e adquirir a sua própria renda, exige-se talento ou qualquer capacidade como recurso especial, plausível de ingressar nos circuitos e cálculos econômicos em opções alternativas. $O$ intuito incide na utilização máxima das competências individuais. Um "vire-se" com suas próprias habilidades e talentos. Vidas-produto, vidas-consumo, vidas-meio: moldáveis, eficazes, replicáveis.

Nesse cenário, a demarcação espacial (regiões, cidades etc.) é essencial para organizar a economia e a sociedade, pois as pessoas criativas procuram áreas com vastas oportunidades de trabalho. Desse modo, buscam-se lugares que ofereçam avanço tecnológico e 24 horas de atividades culturais, esportivas e de lazer para atender a seus estilos de vida marcados por longas jornadas de trabalho em horários flexíveis. 0 ambiente é central para esse critério de capital humano-criativo. Este deve fornecer distração, relaxamento, exercícios físicos, contato com a natureza, ou seja, tudo o que envolve a chamada qualidade de lugar como acoplamento da qualidade de vida. Para os adeptos dessa teoria, a qualidade de lugar deve apresentar três aspectos: o primeiro é a conjugação do ambiente construído com o ambiente natural; o segundo relaciona-se à diversidade de pessoas que interagem na constituição de objetivos comuns; e o terceiro liga-se aos empreendimentos culturais e artísticos que estimulam a criatividade, desde bares até galerias de arte (FLORIDA, 2011). Antes da pandemia do novo coronavírus, tais particularidades eram consideradas imprescindíveis num ambiente favorável para as empresas criativas instalarem-se numa só região. Quiçá, agora, esses espaços sejam modificados ou reorganizados. 
Cabe lembrar que a primeira notícia do mais recente coronavírus chegou em dezembro de 2019 de Wuhan, capital da província de Hubei na China, considerada naquele momento o epicentro da epidemia ${ }^{5}$. Wuhan é uma cidade equiparada ao Vale do Silício pelas características semelhantes à região da Califórnia, nos EUA. Ambos os lugares se distinguem pela efetividade de atrair empresas inovadoras e pela combinação de trabalho, conhecimento, diversão. São metrópoles criativas no padrão dos chamados clusters (do inglês, aglomerados) autossustentáveis, planejados para impulsionar estratégias empresariais de produtividade e competitividade. Entre as características distintivas encontram-se: alta concentração de capital humano-criativo com elevado grau de especialização, passível de dirigir negócios empreendedores; empresas no formato de startups; centros financeiros para aplicação de capitais de risco; universidades e institutos tecnológicos voltados ao desenvolvimento empresarial. O pressuposto basilar dessas cidades reside em acompanhar as mudanças sociais, políticas, culturais e tecnológicas para identificar as circunstâncias favoráveis de mercados. Com pequenas variantes, tais descrições repetem-se em outras cidades dos cinco continentes classificadas de criativas ${ }^{6}$. As cidades criativas parecem ser, então, espaços geográficos prósperos, promessa de um futuro melhor.

No entanto, não é de hoje que fatores econômicos modificam a natureza. Na Inglaterra do século XVI, os cercamentos (enclosure) de terras -antes utilizadas para pastagens comunitárias -, com a finalidade de demarcar os campos para a criação de ovelhas visando suprir a nascente indústria têxtil, demonstraram ser uma prática econômica e jurídica que modificou "a fauna e a flora inglesas" (FOUCAULT, 2016, p. 382). Tal e qual os impactos ocasionados pelos clusters autossustentáveis. Ecossistema de empreendedorismos formado pelo conjunto de setores inovadores. Aglomerados produtivos, amontoado de gente criativa. Condições suficientes para alterar o ambiente natural em favor do ambiente econômico que fomenta prerrogativas concorrenciais. Esses são os projetos de preservação ambiental impulsionados pelo desenvolvimento sustentável, fator primordial nesta fase do capitalismo contemporâneo, que versa em satisfazer, com emprego, as aspirações e necessidades dos seres humanos, sem comprometer o crescimento econômico, fazendo coexistir uma suposta redução da pobreza com uma ampla produtividade (PASSETTI et. al, 2019). Quimera de um futuro melhor, pois enquanto houver capitalismo haverá pobreza e desigualdades.

Enfim, a dispersão do novo coronavírus entre os humanos passou de epidemia a pandemia pelo seu alastramento em todos os cantos do planeta. A pandemia é efeito do capitalismo, que hoje se apresenta como economia criativa e desenvolvimento sustentável. A economia criativa avaliza a constante inovação para ampliar a concorrência, por sua vez, o desenvolvimento sustentável garante o crescimento econômico transformando o meio ambiente natural em capital destinado à perpetuação do capitalismo.

Para o biólogo Rob Wallace, a covid 19 não consiste em nenhuma fabricação laboratorial, conforme os aficionados à teoria da conspiração insistem em divulgar, mas sim está ligada "à produção alimentar e à ren- 
tabilidade das empresas multinacionais" (WALLACE, 2020, p. 11). Segundo ele, para compreender o motivo pelo qual os vírus estão tornando-se cada vez mais graves é preciso indagar o agronegócio, principalmente, o relativo à indústria de exploração animal (humano e não-humano). 0 cientista apresenta a conjunção de elementos capazes de favorecer os vírus pandêmicos. São eles: a monocultura genética dos animais para o consumo que diminui suas proteções imunológicas, o confinamento das espécies para o abate e desmatamento de florestas em benefício da agroindústria favorecendo a migração de animais silvestres para centros urbanos. Relações nem tão difíceis de imaginar, basta ver as declarações do ministro do Meio Ambiente no Brasil, Ricardo Salles, que reputou ser a pandemia uma boa ocasião para mudar as regras relativas à proteção ambiental, posto que a mídia estava voltada à covid-197. Somam-se a esses aspectos as maiores densidades populacionais e a ampla rede global de viagens. Viagens estas em que se destaca, inclusive, a capacidade de mobilidade do capital humano-criativo para galgar posições sociais, aprimorar o conhecimento, aumentar a remuneração.

Em definitivo, sem interromper o fluxo de informações, produtos e transações financeiras, como medida de segurança, alguns países bloquearam as fronteiras territoriais e foram instauradas fronteiras entre os corpos, mediante o isolamento e o distanciamento social. $\mathrm{O}$ isolamento tem por finalidade separar as pessoas doentes das não doentes para evitar a propagação do vírus. Já o distanciamento, segundo as diretrizes sanitárias, implica redução de contato entre as pessoas para amortecer a velocidade de transmissão viral. Tal disposição pressupõe precaver-se da contaminação por indivíduos infectados, assintomáticos, que não estão em isolamento. 0 quanto essas determinações vão emplacar no cotidiano das pessoas ainda é incerto, mas, provavelmente seus efeitos modificarão o governo das condutas pós-pandemia.

\section{Entre os corpos}

Antes que se interprete a questão como estar a favor ou contra o isolamento ou o distanciamento, é bom responder que não se trata disso, tampouco se trata de estar deste e muito menos daquele lado. Trata-se sim de questionar o que decorre dessas medidas. Sob a alegação de guerra ao inimigo comum, novas estratégias de governo justificam decretos como toque de recolher ou estado de emergência, gerando práticas autoritárias, prisões, constrangimentos públicos e deportações. 0 uso figurado da guerra provoca a noção de que a única mobilização social admissível é via forças de segurança, seja polícia seja exército. Aliás, é em nome da segurança que se separam os corpos, porquanto os efeitos desse discurso vão muito além de prevenir a contaminação pelo vírus. São ações governamentais bem precisas, encarregadas de mapear fluxos, gerir processos, homogeneizar diferenças, forjar condutas, capturar revoltas em benefício da economia de mercado fundada na racionalidade neoliberal. 0 presente contexto mostra 
como a segurança solicitada não passa do empenho em querer eliminar os indivíduos tidos como risco social. É em prol da segurança que a polícia mata negros nas ruas $^{8}$, nos supermercados ${ }^{9}$, nas casas $^{10}$, em qualquer lugar. E não quer dizer que algumas forças se tornaram agora mais violentas, apenas ficaram escancaradas num momento de retração social. Haja vista como veio à tona a violência aplicada ininterruptamente sobre os corpos de mulheres, crianças, velhos, homo e transsexuais ${ }^{11}$.

Como se isto não bastasse, os grupos de direita acirraram os ataques contra a imprensa, opositores, o Congresso, o sistema judiciário ${ }^{12}$ ou quem quer que não comungue nem se desdobre aos seus propósitos (MERCIER, 2020). Os mesmos que apoiam que não se feche o comércio, não se pare a economia, assim o Estado não precisa desembolsar recursos. Por detrás das máscaras protetoras, autodenominam-se cidadãos de bem, e invadem hospitais, negam a ciência, espalham boatos. Outros tantos recusam o uso de máscaras e exigem o direito de contagiar-se, a exemplo das reivindicações ocorridas na Alemanha ${ }^{13}$. Há ainda os que assumem publicamente suas convicções e símbolos nazifascistas, deixando à mostra a intencionalidade genocida (MORENO, 2020). Todas estas exibições medonhas, de modo algum, devem ser interpretadas como resistências, pois elas reforçam uma configuração de governo político e econômico acorde com o mercado acima de tudo, a moral reacionária acima de todos, o fuzil apontado para alguns e o iminente extermínio de qualquer um.

Entretanto, nada disso impediu que ocorressem protestos de rua contra o racismo, a derrubada de monumentos de figuras escravocratas inaceitáveis ${ }^{14}$, o apoio mútuo entre as mulheres (CANTO; COMOLI, 2020) e muitas outras atitudes combativas, bem distantes da caridade passageira em que quem ajuda mantém a superioridade diante de quem é ajudado. $\mathrm{E}$ não se confundem, em absoluto, com as doações de empresas e empresários ávidos para viabilizar o abatimento do imposto de renda ${ }^{15}$. Algumas dessas empresas no Brasil até mesmo tiveram seu momento de extermínio pelo rompimento de barragens, outras oriundas de países com altos índices de desenvolvimento humano e políticas ambientais, em inúmeras ocasiões, não deixaram de jogar toneladas de rejeitos em nascentes amazônicas, contaminando as populações locais, a fauna e a flora ${ }^{16}$. Modus operandi do capital: engolfar no mercado global as regiões afastadas das aglomerações urbanas. "A quase totalidade do projeto neoliberal está organizada em torno do apoio aos esforços das empresas sediadas nos países industrializados mais avançados para roubar a terra e os recursos dos países mais fracos" (WALLACE, 2020, p. 11).

Vivencia-se hoje um período aflitivo, intrincado e em transição. Por esse motivo, toda e qualquer análise deve ser cautelosa, sobretudo, quanto à abordagem em torno do isolamento e/ou distanciamento. Em certas situações, a separação física sugere uma dimensão moral e, portanto, política do chamado futuro novo normal. Medidas começaram a ser implementadas em equipamentos de espaços públicos, fora os projetos de arquitetos e designers que vaticinam a redefinição de instalações urbanas e a produção 
de objetos. A premissa é manter o distanciamento físico, e as diretrizes de um a dois metros de distância entre os corpos apontam para uma atualização do capitalismo que implica num reordenamento político e econômico. É bom lembrar que o capitalismo, para manter sua vigência, renova-se constantemente, e os momentos de crise (política, econômica, sanitária etc.) são a forma corriqueira de governar na racionalidade neoliberal: proporcionar opções às políticas existentes exprime transformar o politicamente improvável em politicamente indispensável, como outrora anunciado por Milton Friedman, um dos formuladores do neoliberalismo (KLEIN, 2008). Dito de outra maneira, converter as regulamentações provisórias em permanentes. E não são as pautas ligadas à esmola do "auxílio emergencial"17, mesmo porque esse auxílio é cortado rapidamente, mas as relacionadas aos projetos de distribuição de cargos públicos para reacionários, privatização, reforma tributária, comercialização de armas, mineração em terras indígenas, garantia da lei e da ordem etc. Todo um roteiro defendido pelos correligionários do presidente em exercício, que pouco se importam com a morte de mais de uma pessoa por minuto.

Outrossim, a crise pandêmica demonstrou como, na economia orientada pela criatividade, esta circunstância se converteu em iniciativas inovadoras ou oportunidades de bons negócios. O que também salta aos olhos em projetos de design recentes, desprovidos de funcionalidade e ergonomia exigidas num "bom design". Como é o caso do capacete gigantesco proposto pela startup canadense VYZR Technologies ${ }^{18}$, sob a justificativa de as pessoas precisarem adaptar-se ao novo normal para a economia voltar a operar, ou um escudo desenvolvido no escritório chinês Penda ${ }^{19}$, com o qual o indivíduo isola-se num ambiente esterilizado, e ainda outro, elaborado pela empresa Designlibero ${ }^{20}$, em forma de bolha, que serve para blindar a pessoa em espaços públicos. Não é necessário ser designer para notar a inviabilidade do uso desses artefatos num ambiente urbano, no transporte coletivo, ou mesmo a dificuldade de seu manuseio, entre demais questões. Em Amsterdã, outro exemplo, designers planejaram cabines com lugares para três pessoas recomendadas para quem mora junto, com o propósito de reinterpretar o conceito de união ${ }^{21}$. Ora, são essas adaptações espaciais e a criação de objetos que materializam a normalização da separação progressiva entre os corpos, com a qual se facilita o controle cada vez mais individualizado. A saber: com ou sem vírus, o controle é exercido contínua e irrestritamente sobre cada um. Tanto a céu aberto quanto por meio das tecnologias digitais de informação e comunicação, como bem sublinhou Gilles Deleuze (2004) ao explicitar a sociedade de controle.

Esta pandemia, ademais, acelerou a implantação de determinados projetos bastante promissores na racionalidade neoliberal: o trabalho remoto (home office) e a educação a distância (EAD). Empresas especializadas em tecnologia computacional logo começaram a disponibilizar instrumentos de produtividade para adequar o trabalho e o ensino. A nova demanda impulsionou estratégias de negócios em corporações como Google, Microsoft, Zoom, Slack, entre outras classificadas de "altamente criativas". 
Assim, com a finalidade de obter bons resultados, as ferramentas desenvolvidas são capazes de gerir as tarefas individuais ou em grupo, estipular prazos, armazenar dados, monitorar atividades e seus respectivos tempos. Tudo com uma redução expressiva dos custos fixos das empresas privadas e estatais. Cabe lembrar que áreas da economia criativa ligadas ao consumo de equipamentos culturais e moda também indicam alterações. A tecnologia de streaming, apropriada para transmitir de maneira instantânea dados de áudio e vídeo pelas redes, aumentou exponencialmente durante a interminável quarentena. Tal tecnologia permite, inclusive, a transmissão ao vivo de eventos proporcionando maior disseminação e interação em tempo real. À semelhança das aulas e do trabalho remotos, o consumo cultural certamente irá apresentar mudanças no novo normal, quer dizer, nesses três setores, sem dúvida, uma alteração, todavia, há algum tempo anunciada. $\mathrm{E}$ que provavelmente será mantida para além da prevenção do contágio viral, se não totalmente, como sistema híbrido.

É curioso como as pessoas, independentemente de suas posições quanto às disposições sanitárias, não questionam as estratégias de isolamento e distanciamento relacionadas ao chamado novo normal que naturalizam os procedimentos acima descritos; pelo contrário, as aceitam com entusiasmo. Decerto porque são estratégias que se apresentam ao indivíduo como garantia de segurança, no que diz respeito às áreas denominadas de "automação inteligente". As pessoas imaginam que fazem um uso seguro da máquina e estão no comando dela, mas essa segurança, na realidade, possibilita mapear o usuário, decifrar códigos, identificar padrões, detectar tendências de fluxos, produzir banco de dados, gerir condutas. Tudo milimetricamente controlado.

Não por acaso, a "inteligência criativa" empenhou-se em produzir a "inteligência artificial" (IA), que, aliada, por exemplo, ao design emocional ${ }^{22}$, procura estimular a crença de ser exclusivo, de estar protegido, de ter liberdades civis garantidas. Sem embargo, a finalidade é induzir um amplo abastecimento de dados na tentativa de controlar pessoas, coisas, informações. Para uma parte privilegiada da sociedade, quase tudo pode ser efetuado desde seus aparelhos eletrônicos, viabilizando, através das plataformas digitas interligadas, todo o registro de suas existências. Para aqueles que obrigatoriamente precisam sair à rua para trabalhar - e são os que atendem quem ficou seguro em casa -, a IA colabora ao decodificar cada movimento, identificar a posição geográfica, catalogar a eficiência. Com isso, facilita-se uma centralização meticulosa de dados sofisticando controle, persuasão e condução de condutas, numa parceria fértil entre organizações governamentais e as empresas da chamada alta tecnologia.

Antes da covid-19, a IA apresentava-se sob o argumento de personalizar o produto ou o serviço e facilitar o cotidiano. Hoje, ela se vende, praticamente sem oposição, com base no discurso de proteger as pessoas seja desta ou de outras pandemias, seja de virtuais perigosos. Desse modo, as cidades criativas vão fundindo-se ou transmutando-se em cidades inteligentes. Lugares onde se privilegiam as "redes inteligentes" de energia, água, 
coleta de resíduos, iluminação pública, além do rastreamento mediante wi-fi gratuito, sensores em bancos de praças, semáforos e lixeiras. Localidades onde os pagamentos são feitos via aplicativos, que decifram códigos de barras bidimensionais convertendo-os em recursos disponíveis na rede para identificar qualquer localização georreferenciada, endereço eletrônico, contato etc. Regiões onde a população consegue, por meio de aplicativos, saber tudo o que sucede na cidade em tempo real e onde, se, por acaso, algo escapar do controle efetuado pela tecnologia, haverá sempre algum sujeito que se encarregue de acusar quem quer que ele julgue suspeito ou perigoso.

\section{Tomar conta de si}

Para viabilizar seus projetos criativos, os indivíduos efetuam cálculos e apostas, tendo em vista remover obstáculos que impeçam a autorrealização e o sucesso. $O$ cálculo é efetuado com base naquilo que podem perder ao escolherem a carreira, o casamento, o emprego, as parcerias. Já as apostas são arroladas segundo os resultados obtidos no momento imediato de qualquer evento favorável ou na projeção da promissora escolha. Antecipar as possibilidades futuras pressupõe precaver-se de quaisquer ameaças, por isso, tenta-se identificar os perigos e, caso necessário, mudar a estratégia de tal maneira que o investimento pessoal, os vínculos convenientes e o ambiente propício sejam protegidos. Medidas, porém, inócuas quando colocadas cara a cara com o novo coronavírus.

Em termos nietzschianos a "grande saúde" não é algo que, de repente, descobrimos, mas aquilo que precisamos, sem tréguas, ser. Ou seja, implica deixar de lado posturas de aceitação que geram uma condição de vida doentia para aprender a tomar conta de si, daquilo que se faz, se pensa, se sente, evitando que outros façam isso por nós. Certamente, toda doença aflige o humano, todavia ela também pode encorajar as pessoas a abandonar a continuidade de um projeto fundante, para correr o risco de não ser mais quem se é; pelo menos, isso seria o esperado quando estamos diante de tantas mortes provocadas pela covid-19. Temos que encarar a morte afirmando a vida como algo único, imediato, intenso. Vivenciar esta pandemia incide em compreendê-la dentro dela mesma, visando uma mudança que comece em cada um. O que não exprime, de jeito algum, intensificar ainda mais a individualização, característica marcante das subjetividades forjadas pelo capitalismo. Tampouco sugere relativizar o estado das coisas a ponto de, sob o manto do discurso da democratização, justificar extermínios de humanos e não humanos. Imprime, isto sim, inventar um modo de vida capaz de curto-circuitar o controle, bem como a política e a economia voltadas à proliferação de enfermidades. Ocupar-se daquilo que ingerimos, usamos, produzimos na mesma proporção em que temos que nos ocupar das próprias lutas contra o inimigo imediato, cujas ações, enquanto efeitos do poder, se exercem diretamente sobre nós. Uma atitude individual, sem, no entanto, ser unicamente de interesse particular e satisfação pró- 
pria, mas uma experiência que, de certo modo, chega aos outros e pode ser experimentada numa prática coletiva. Atitude coletiva distante da ação gregária ou "moral do rebanho" analisada por Friedrich Nietzsche, a qual se funda na equação de mando e obediência (NIETZSCHE, 2006, 2001; 1999). Por conseguinte, não são vínculos que alimentam a adequação, a sujeição e a conformidade.

Tomar as rédeas da própria vida não se confunde com a responsabilidade proferida pela racionalidade neoliberal, segundo a qual os indivíduos devem garantir-se contra possíveis riscos em suas existências, restringindo a autonomia ao âmbito econômico como capacidade de responsabilizar-se pela própria renda e manutenção: uma vida reduzida à sobrevivência. Trata-se, diferentemente, de ocupar-se com quem se é, o que somos capazes de ser, o que precisamos questionar, compreender ou ultrapassar. Refere-se, ao mesmo tempo, a manter-se longe dos passivos, ressentidos, gregários e não esperar pela salvação do além, nem do aquém com suas míseras ajudas. Aliás, atitudes a serem praticadas com ou sem pandemias. Ocupar-se consigo dessa maneira demanda agir com e pelo outro sem necessidade de medidas impositivas nem mediações. Assim, é possível extrair desta doença saberes que o humano orientado pelo capitalismo é incapaz de aprender, pois este humano se importa demais com aquilo que pode perder ou deixar de ganhar.

Nesse sentido, conviver com os outros em meio à pandemia requer distinguir quando temos ou não que aguardar. Aguardar não com o torpor dos adaptáveis, submissos, resignados, mas como condição para o fortalecimento e a audácia. Em parte, compreendem-se certas argumentações quando apontam que as pessoas que estão se divertindo no fim do expediente laboral ou aos finais de semana são, na maioria das vezes, os mesmos trabalhadores expostos ao vírus, obrigados a enfrentar conduções lotadas e a exploração diária para obter o ganha pão. Contudo, quando analisada essa premissa, nota-se, pelo avesso, uma moral proveniente da lógica capitalista que não se desfez. Muito pelo contrário, sob tais alegações sedimenta-se a individualização. E mais, quem se dispõe só a obedecer às ordens emanadas de posições hierarquicamente superiores, é porque também sabe e quer mandar quando chegar a sua vez, isso demonstra uma constituição cultural autoritária.

Os aglomerados de gente sem máscara ocorridos na virada do $a^{23} o^{23}$ $(2020 / 21)$ e durante o carnaval ${ }^{24}$ provocam o seguinte questionamento: por que, em face da política de extermínio preconizada pelo governo do Estado brasileiro e seu séquito, das condições precárias da maior parte da população, dos autoritarismos e de um sem-fim de desprezos, esses milhares de pessoas não se revoltam? E de modo algum ignoram-se os protestos dos entregadores de aplicativos (SCHAVELZON, 2020), das torcidas organizadas ${ }^{25} \mathrm{~W}$ ou, como anteriormente mencionado, dos grupos antirracistas etc., que se deram, no entanto, com menos frequência que as aglomerações por entretenimento. Eis o ponto: diversão como "válvula de escape" para voltar ao trabalho satisfeitos. Tempo previsto na economia criativa para aprimorar as performances do capital humano. Sociabilidade inerente ao presente contexto, em que o mais importante é recrutar seguidores, ganhar "curti- 
das" nas redes sociais pelas postagens de fotos, vídeos e frases replicadas inúmeras vezes. Nada comparado a uma conversa, aos silêncios, aos gestos, à troca de olhares, ao andar junto, às digressões passageiras daqueles que dividem muito mais que um espaço comum. Sendo assim, a separação necessária e a aproximação cautelosa dos corpos são atitudes imprescindíveis para gerar uma potência de viver, muito além da sobrevivência.

Não há aqui uma conclusão ou considerações finais. $O$ que se propõe, ao revés, é uma espécie de abertura, para se pensar junto a possibilidade de tomar conta de si descolando-se da operacionalização dos objetivos da racionalidade neoliberal, mesmo que parcialmente. Atitudes que abandonem o processo de projetar as vidas para gerir condutas resignadas. Ações realizadas por aqueles que queiram interromper a lógica da inovação canalizada na extração de resultados mercadológicos satisfatórios, alicerce do capitalismo contemporâneo. Resistências capazes de agir constantemente nos interstícios do cotidiano, não para esperar ou prometer um futuro melhor, senão para combater aquilo que funciona e se estabelece como padrão a ser seguido. Resistências singulares, situadas fora da capitalização de vidas.

1 Disponível em: (https://g1.globo.com/bemestar/coronavirus/noticia/2021/03/10/brasil-supera-2-mil-mortes-registradas-em-24-horas-veja-quais-paises-tem-a-mesma-marca-e-o-que-ela-significa.ghtml) Acesso em: 14/03/2021.

2 Ação de lançar para a frente, de se estender, extensão. Particípio de projicĕre, que é projétil e denota lançar para diante. Dicionário latino-português Disponível em: (http://www.dominiopublico.gov.br/download/ texto/me001612.pdf) Acesso em: 25/03/2021.

3 Disponível em: (https://www.senado.gov.br/noticias/Jornal/emdiscussao/rio20/a-rio20/conferencia-rio-92-sobre-o-meio-ambiente-do-planeta-desenvolvimento-sustentavel-dos-paises.aspx) Acesso em: 25/03/2021.

4 Disponível em: (https://www.un.org/spanish/esa/sustdev/agenda21/ riodeclaration.htm) e (https://www.un.org/spanish/esa/sustdev/agenda21/agenda21sptoc.htm). Acesso em: 25/01/2021.

5 Para mais informações sobre a cidade de Wuhan e a nova epidemia viral, a editora Veneta publicou e disponibilizou gratuitamente um extenso artigo escrito pelo coletivo chinês Chuang, intitulado "Contágio social". Disponível em: (https://veneta.com.br/produto/contagio-social-pdf/) Acesso em: 25/03/2021.

6 Cidades criativas. Disponível em: (https://en.unesco.org/creative-cities/creative-cities-map). Acesso em 15/01/2020.

7 A declaração do ministro foi amplamente divulgada no Brasil e no exterior. A título informativo consultar as referências disponíveis em: (https://g1.globo.com/politica/noticia/2020/05/22/ministro-do-meio-ambiente-defende-passar-a-boiada-e-mudar-regramento-e-simplificar-normas.ghtml); e vídeo em: (https://noticias.uol.com.br/ videos/2020/05/23/salles-defende-aproveitar-momento-para-passar-a-boiada-e-simplificar-normas.htm). Acesso em: 25/03/2021

8 Disponível em: (https://g1.globo.com/mundo/noticia/2020/05/27/ caso-george-floyd-morte-de-homem-negro-filmado-com-policial-branco-com-joelhos-em-seu-pescoco-causa-indignacao-nos-eua.ghtml). Acesso em 02/02/2021. 
9 Disponível em: (https://oglobo.globo.com/sociedade/homem-negro-espancado-ate-morte-por-segurancas-em-supermercado-de-porto-alegre-1-24757368). Acesso em 02/02/2021.

10 Disponível em: (https://g1.globo.com/jornal-nacional/noticia/2020/05/19/policia-abre-inquerito-para-investigar-morte-de-jovem-de-14-anos-em-operacao-policial-no-rj.ghtml). Acesso em: 03/02/2021. 11 Para mais informações consultar dados no "Atlas da violência 2020". Disponível em: (https://www.ipea.gov.br/atlasviolencia/download/27/ atlas-da-violencia-2020-principais-resultados) Acesso em: 03/03/2021. 120 próprio Senado publicou notas contra os atos promovidos pelo presidente e seus seguidores. Disponível em: (https://www12.senado. leg.br/noticias/materias/2020/06/15/senadores-condenam-avanco-de-manifestacoes-antidemocraticas). Acesso em: 13/02/2021.

13 Disponível em: (https://www.dw.com/pt-br/entenda-a-onda-de-protestos-de-extrema-direita-na-alemanha/a-45261598). Informação complementar disponível em: (https://gauchazh.clicrbs.com.br/mundo/ noticia/2020/05/direito-de-se-contagiar-milhares-vao-as-ruas-na-alemanha-protestar-contra-confinamento-cka9ww4s5016001pfs6avt35e. html). Acessos em: 25/02/2021.

14 Consultar "A luta é pela vida" Parte I". Disponível em: (https://faccaoficticia.noblogs.org/post/2020/03/22/luta-pela-vida/) e "A luta é pela vida" Parte II. Disponível em: (https://faccaoficticia.noblogs.org/ post/2020/04/13/a-luta-e-pela-vida-parte-ii/). Acessos em: 14/01/2021. 15 Disponível em: (https://www.camara.leg.br/proposicoesWeb/fichadetramitacao?idProposicao=2251954) Acesso em 18/01/2021.

16 A exemplo da Vale Canada Limited uma subsidiária da empresa brasileira de mineração Vale e da mineradora norueguesa Hydro que tinha um duto clandestino para lançar os detritos não tratados.

17 Trata-se de um recurso financeiro outorgado pelo governo federal durante a pandemia do novo coronavírus. Disponível em: (https://www. gov.br/cidadania/pt-br).

18 Disponível em: (https://www.indiegogo.com/projects/biovyzr-venture-out-breathe-easy\#/) Acesso em: 16/02/ 2021.

19 Disponível em: (https://www.plasticstoday.com/medical/batman-inspired-shield-would-protect-wearers-coronavirus/144653247562574) Acesso em: 18/02/2021.

20 Disponível em: (https://www.businessinsider.com/plastic-bubble-shield-design-to-stop-coronavirus-spread-2020-4\#the-top-and-bottom-are-connected-by-a-zipper-for-an-easy-way-to-put-the-shield-on-and-remove-it-2) Acesso em: 18/02/2021.

21 Disponível em: (https://www.archdaily.com/939806/serres-separees-proposes-a-socially-distant-dining-experience-in-amsterdam) Acesso em: 20/02/ 2021.

220 design emocional enaltece a satisfação dos indivíduos com o uso do produto ou serviço, deixando-se em segundo plano os aspectos formais e funcionais do objeto.

23 A título de exemplo verificar a dimensão dessas aglomerações em: (https://www.bol.uol.com.br/noticias/2021/01/04/sp-barrou-6700-em-festas-ilegais-no-natal-e-ano-novo-e-fechou-11-locais.htm). Acesso em: 12/03/2021.

24 Em caráter informativo consultar a avaliação disponível em: (https:// g1.globo.com/bemestar/coronavirus/noticia/2021/02/14/apesar-de-proibicao-de-eventos-de-carnaval-aglomeracoes-sao-registradas-em-varias-partes-do-pais.ghtml). Acesso em: 12/03/2021.

25 Disponível em: (https://catracalivre.com.br/cidadania/gavioes-e-outras-torcidas-fazem-protesto-antifascismo-na-paulista/) Acesso em: 03/03/2021 


\section{Referências}

CANTO, K; COMOLI, E. "Pandemia impacta mais a vida das mulheres". In: Cultura e sociedade, Lab 19. Campinas: UNICAMP, 2020. Disponível em: (https://www.unicamp.br/unicamp/ noticias/2020/08/19/pandemia-impacta-mais-vida-das-mulheres).

FLORIDA, Richard. A ascensão da classe criativa. Tradução de Ana Luiza Lopes. Porto Alegre, RS: L\&PM, 2011.

FOUCAULT, Michel. “Crise da medicina ou crise da antimedicina?”. In: MOTTA, Manoel Barros (org.). Arte, epistemologia, filosofia e história da medicina (Ditos e Escritos, vol. VII). Tradução de Vera Lucia Avellar Ribeiro. Rio de Janeiro: Forense Universitária, 2016, pp. 334-393. FOUCAULT, Michel. Nascimento da biopolítica: curso no Collége de France (1978 - 1979). Tradução de Eduardo Brandão. São Paulo: Martins Fontes, 2008 - (Coleção tópicos).

KLEIN, Naomi. A doutrina do choque: a ascensão do capitalismo desastre. Tradução de Vania Cury. Rio de Janeiro: Nova Fronteira, 2008.

MARTINEZ, Adriana V. Ferreira de. 0 design das formas políticas na governamentalidade neoliberal. São Paulo: PUC-SP, 2020. Tese de doutorado em Ciências Sociais. Disponível em: (https://tede2.pucsp.br/handle/handle/23387).

MERCIER, Daniela. "Bolsonaro endossa ato pró-intervenção militar e provoca reação de Maia, STF e governadores". In: El País, São Paulo, 19 de abril de 2020. Disponível em: (https://brasil.elpais.com/politica/2020-04-19/bolsonaro-endossa-ato-pro-intervencao-militar-e-provoca-reacao-de-maia-stf-e-governadores.html).

MORENO, Jesus. "Pandemia pode elevar risco de 'extremismo de extrema direita'". In: BBC|Brasil, 12 de dezembro de 2020. Disponível em: (https://www.bbc.com/portuguese/internacional-55005784).

NIETZSCHE, Friedrich. Além do bem e do mal: prelúdio a uma filosofia do futuro. Tradução de Paulo César de Souza. São Paulo: Companhia das letras, 2006.

NIETZSCHE, Friedrich. A gaia ciência. Tradução de Paulo César de Souza. São Paulo: Companhia das Letras, 2001.

NIETZSCHE, Friedrich Genealogia da moral: uma polêmica. Tradução de Paulo César de Souza. São Paulo: Companhia das Letras, 1999.

ONU. Organização das Nações Unidas. “Agenda 21”, 1992. Disponível em: (https://www. un.org/esa/dsd/agenda21_spanish/).

PASSETTI, Edson (coord.) et al. Ecopolítica. São Paulo: Editora Hedra Ltda, 2019.

SCHAVELZON, Salvador. "A luta dos entregadores de aplicativo contra os algoritmos autoritários”. In: El País, São Paulo, 25 de julho de 2020. Disponível em: (https://brasil.elpais. com/opiniao/2020-07-25/a-luta-dos-entregadores-de-aplicativo-contra-os-algoritmos-autoritarios.html).

SCHUMPETER, Joseph A. Capitalismo, socialismo e Democracia. Tradução de Ruy Jungmann. Rio de Janeiro: Editora Fundo de Cultura, 2017.

WALLACE, Rob. Pandemia e agronegócio: entrevista com Rob Wallace. Revista Tormenta, ano 1, ed. \#00, pp. 8-16, 2020. Disponível em: (https://faccaoficticia.noblogs.org/files/2020/12/revista-2020-LIMPO-1.pdf).

Recebido: 15 de fevereiro de 2021. Aprovado: 05 de março de 2021. 